\title{
Recurrence after pituitary surgery in adult Cushing's disease: a systematic review on diagnosis and treatment
}

\author{
Leah T. Braun $\mathbb{1}^{1}$ - German Rubinstein ${ }^{1}$ - Stephanie Zopp ${ }^{1}$ - Frederick Vogel ${ }^{1} \cdot$ Christine Schmid-Tannwald $^{2}$. \\ Montserrat Pazos Escudero ${ }^{3} \cdot$ Jürgen Honegger ${ }^{4} \cdot$ Roland Ladurner $^{5} \cdot$ Martin Reincke $^{1}$
}

Received: 13 May 2020 / Accepted: 20 July 2020 / Published online: 2 August 2020

(c) The Author(s) 2020

\begin{abstract}
Purpose Recurrence after pituitary surgery in Cushing's disease (CD) is a common problem ranging from 5\% (minimum) to $50 \%$ (maximum) after initially successful surgery, respectively. In this review, we give an overview of the current literature regarding prevalence, diagnosis, and therapeutic options of recurrent $\mathrm{CD}$.

Methods We systematically screened the literature regarding recurrent and persistent Cushing's disease using the MESH term Cushing's disease and recurrence. Of 717 results in PubMed, all manuscripts in English and German published between 1980 and April 2020 were screened. Case reports, comments, publications focusing on pediatric CD or CD in veterinary disciplines or studies with very small sample size (patient number $<10$ ) were excluded. Also, papers on CD in pregnancy were not included in this review.

Results and conclusions Because of the high incidence of recurrence in CD, annual clinical and biochemical follow-up is paramount. 50\% of recurrences occur during the first 50 months after first surgery. In case of recurrence, treatment options include second surgery, pituitary radiation, targeted medical therapy to control hypercortisolism, and bilateral adrenalectomy. Success rates of all these treatment options vary between 25 (some of the medical therapy) and 100\% (bilateral adrenalectomy). All treatment options have specific advantages, limitations, and side effects. Therefore, treatment decisions have to be individualized according to the specific needs of the patient.
\end{abstract}

Keywords Hypercortisolism $\cdot$ Cushing's syndrome $\cdot$ Pituitary adenoma $\cdot$ Adrenostatic therapy

\section{Introduction}

Cushing's syndrome (CS) is in 60-85\% of cases ACTHdependent. Most frequently it is caused by a corticotroph

Martin Reincke

Martin.Reincke@med.uni-muenchen.de

1 Department of Endocrinology, Medizinische Klinik und Poliklinik IV, Klinikum der Universität München, München, Germany

2 Klinik und Poliklinik für Radiologie, Klinikum der Universität München, München, Germany

3 Klinik und Poliklinik für Strahlentherapie und Radioonkologie, Klinikum der Universität München, München, Germany

4 Department for Neurosurgery, University Hospital Tübingen, 72076 Tübingen, Germany

5 Klinik für Allgemeine, Unfall- und Wiederherstellungschirurgie, Campus Innenstadt, Klinikum der Universität München, München, Germany adenoma of the pituitary gland [1]. The recommended screening tests for hypercortisolism include the low-dose dexamethasone suppression test (LDDST with $1 \mathrm{mg}$ ), urinary free cortisol in a $24 \mathrm{~h}$-output-collection (UFC), and midnight salivary cortisol measurement. The tests for subtyping include the high-dose-dexamethasone suppression test, the CRH test, and in some cases the inferior petrosal sampling. According to recent systematic meta-analyses, first-line therapy is transsphenoidal surgery which leads to remission in $71 \%$ [2], $80 \%$ [3] or $78 \%$ of cases [4]. However, there are still open questions regarding diagnosis and therapy of recurrent $\mathrm{CD}$. To summarize the current research in this field and to identify knowledge gaps, we conducted a systematic review.

\section{Methods}

We systematically screened the literature regarding recurrent and persistent Cushing's disease (CD) using the MESH 
term Cushing's disease and recurrence in PubMed. We identified 717 studies published between 1980 and April 2020, of which 692 were in English or German. Of these manuscripts, 134 were fully considered after excluding case reports, comments, reviews without meta-analysis, publications focusing on pediatric $\mathrm{CD}$ or $\mathrm{CD}$ in veterinary disciplines, $\mathrm{CD}$ in pregnancy and very small studies with sample size $<10$ patients. Table 1 summarizes major studies with $\geq 100$ patients with CD published between 1983 and 2018 in which recurrence after first transsphenoidal surgery was analyzed.

\section{Definition of recurrence and persistency}

Remission following transsphenoidal surgery is most often defined by low morning cortisol levels $(<1.8 \mu \mathrm{g} / \mathrm{dl} ; 50 \mathrm{nmol} /$ L) [5] and the requirement of glucocorticoid replacement therapy. Obviously, there may be patients who do not fulfill this cut-off but still enter remission. In contrast to disease persistence after transsphenoidal surgery, the definition of recurrence requires a phase of months to years of disease remission, which then is followed by re-appearance of CD. Remission criteria vary between studies (see Table 1), which is one possible explanation for different remission and recurrence rates in different studies. While remission criteria are not standardized, recurrence criteria are also not consistent throughout different studies. Most of the studies define recurrence by an elevated UFC or elevated serum cortisol-criteria, which are not the most sensitive and specific markers.

\section{Diagnosis of recurrence}

\section{Prevalence of recurrence after pituitary surgery}

$\mathrm{CD}$ recurs in $\sim 14 \%$ of patients $(5-21 \%)$ between 3 and 158 months (mean 51 months) [4]. Fifty percent of relapses occur during the first 15-50 months after initial surgery [6]. However, late recurrences after decades of remission are possible [7]. A regular follow-up is therefore mandatory and a consistent recommendation in several studies and guidelines [8-11]. Recurrence rates differ greatly between the studies, most likely due to varying definitions of remission and recurrence, and also due to different surgical approaches and length of follow-up [12]. The recurrence rate is higher with longer follow-up, as already stated in 1992 by Tahir and Sheeler and shown in Table 1 [13]. In addition, comparisons among studies is difficult since, for example, few patients with negative MRI at baseline are included in some series [14], a factor that influences success greatly [15]. According to our research, recurrence of $\mathrm{CD}$ is mostly defined by biochemical criteria, while clinical signs and symptoms are often not mentioned and, therefore, apparently not compulsory. This scenario creates a level of ambiguity since biochemical evidence of hypercortisolism is not per se specific and sensitive. Examples for the latter are mild recurrence or cyclic CS [16] and for the former physiological forms of hypercortisolism (i.e., in major depression), which can also be typical in the postoperative phase of CD.

According to a recent multicenter study by Geer et al. the clinical practice situation in the US shows that transsphenoidal surgery is in more than $50 \%$ of the cases initially unsuccessful [17]. This study was retrospective based on data from medical records from 230 patients. Mean followup was quite short with 3 years (median 1.9, range 0-27.5 years) and a lot of data were missing. For example, there were no MRI results available for 90 patients [17]. After initial surgery, only 91 patients were in remission and, at the end of the observation period, 110 patients $(49.1 \%)$ achieved remission using additional treatment strategies. Remission was not achieved in the other 67 patients, data of 47 patients were missing. Summarized, results from this study should be evaluated with caution as outcome differs greatly from results of recent meta-analysis. However, it is a warning signal that surgical series from expert neurosurgery centers may not reflect real world scenarios, in which access to expert centers and optimized follow-up may be limited.

\section{Factors influencing recurrence}

Many studies have focused on factors influencing the remission state of patients with $\mathrm{CD}$ (summary shown in Table 2). In a single-center study, remission rates in macroadenomas are higher than in microadenomas [18], opposite to the findings of a recent metanalysis [19] and most of the other studies. Experience of the surgeon influences outcome, morbidity, and mortality $[4,20]$. In a multicenter, retrospective European study of 668 patients remission rates were associated with pre-surgical identification of the tumor by MRI, an observation also reported by Chee et al. [21]. It was also higher in patients with long-term glucocorticoid replacement therapy and those with low postoperative cortisol levels [7], whereas only a minority did not confirm the latter [22-24].

According to a study by Liu et al. using different machine learning algorithms, the most important predictors for recurrence were young age, postoperative serum cortisol, and postoperative ACTH, both measured in the first 7 days after surgery (cut-offs see Table 2) [25]. However, sensitivity and specificity using such an algorithm were quite low with $87 \%$ and $58 \%$, respectively.

In a retrospective study with 41 patients with $\mathrm{CD}$, higher ACTH levels pre-surgery were one predictor for recurrence, while lower DHEA levels pre-surgery and a larger decrease 


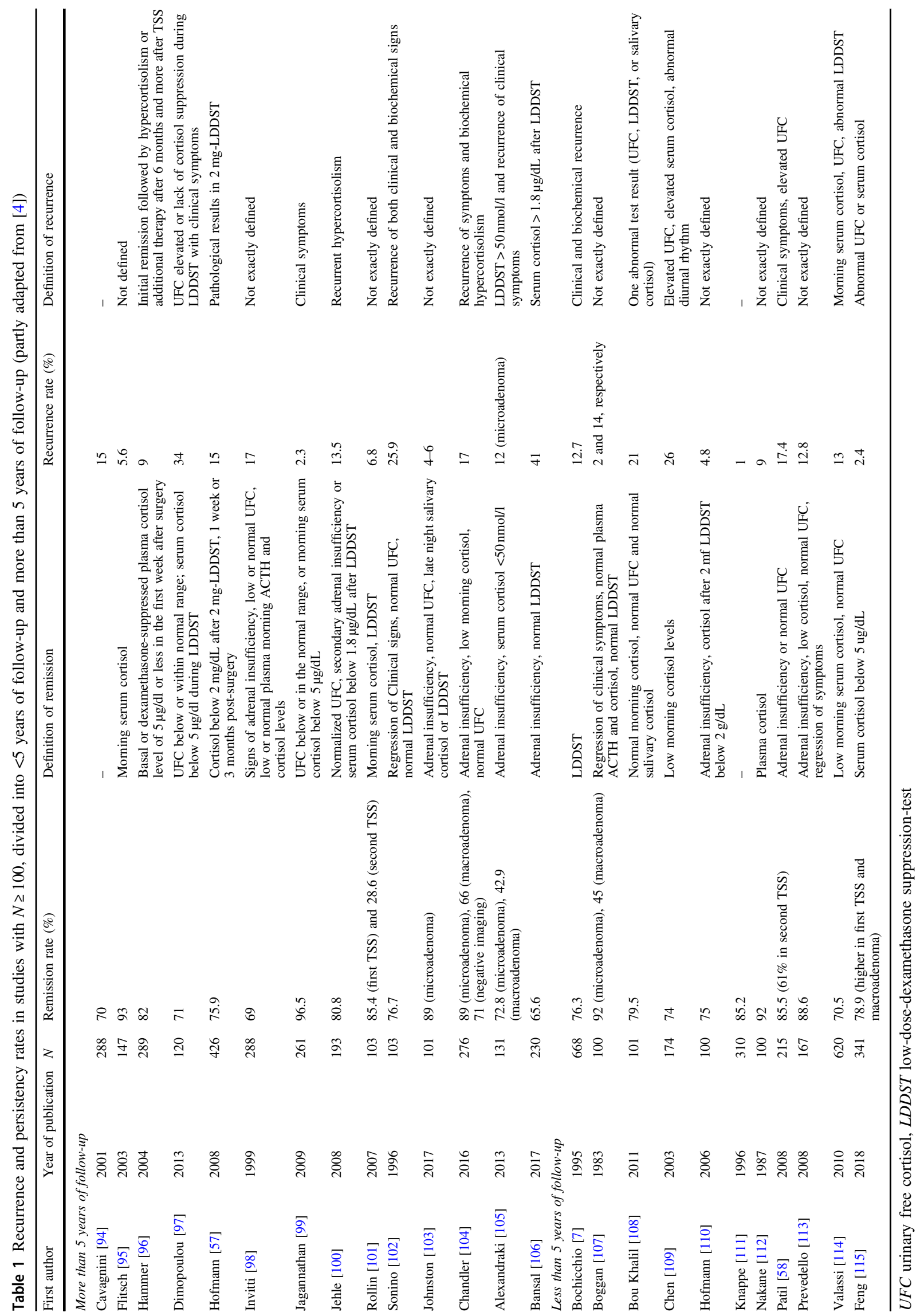


Table 2 Predictors for remission

\begin{tabular}{ll}
\hline Predictors for remission & Studies
\end{tabular}

- Identification of the tumor pre-surgery by MRI

- No invasion of the sinus cavernosus by the adenoma

- Low postoperative cortisol levels (below normal ranges or not measurable, $<2 \mu \mathrm{g} / \mathrm{dL}$ )

- Low cortisol levels 6-12 weeks after surgery $(<35 \mathrm{nmol} / \mathrm{l})$

- Long-term replacement therapy required ( $>1$ year), long term of hypocortisolism ( $>1$ year)

- Low postoperative ACTH levels (mean $7.9 \mathrm{ng} / \mathrm{L}$ or mean $13 \mathrm{pg} / \mathrm{ml}$, respectively), ACTH value $<3.3 \mathrm{pmol} / \mathrm{L}$ postoperative

- Histological confirmation of adenoma

- Lower DHEA levels pre-surgery

- Lower ACTH levels pre-surgery (mean = $71 \mathrm{ng} / \mathrm{L})$

- Significant decrease of BMI post-surgery

- Experience of the surgeon/the center

- Age (mean age 35 years; recurrence more often in younger age below 35 years)

- No USP8 mutant coricotroph tumor

- Short time to recovery from postoperative adrenal insufficiency

- Postoperative cortisol response to desmopressin (delta < $193 \mathrm{nmol} / \mathrm{l})$, low cortisol and ACTH peak after desmopressin, response to desmopressin after 6 months

- Post-surgery 11-deoxycortisol < $150 \mathrm{nmol} / \mathrm{l}$ after metyrapone-test

- Cortisol $<49 \mathrm{nmol} / \mathrm{L}$ in a $48 \mathrm{~h}$ suppression test with betamethasone $2 \mathrm{mg} / \mathrm{day}$
Bochicchio et al. 1995 [7], Chee et al. 2001 [21]

Cannavo et al. 2003 [116]

Bochicchio et al. 1995 [7], Liu et al. 2019 [25], Fleseriu et al. 2016

[34], Pieters et al.1989 [117], Lindsay et al. 2011 [118], Aranda et al. 2015 [119], Imaki et al. 2001 [120], Ironside et al. 2018 [121],

Mayberg et al. 2018 [122]

Toms et al. 1993 [123]

Bochicchio et al. 1995 [7], Bansal et al. 2017 [106]

Liu et al. 2019 [25], Kuo et al. 2017 [26], Abellan-Galiana et al. 2019 [124]

Pouratian et al. 2007 [29], Serban et al. 2020 [125]

Kuo et al. 2017 [26]

Liu et al. 2019 [25], Kuo et al. 2017 [26], Selek et al. 2018 [126]

Kuo et al. 2017 [26]

Barker et al. 2003 [20], Honegger et al. 2018 [55], Rees et al. 2002 [127], Serban et al. 2020 [125]

Liu et al. 2019 [25]

Albani et al. 2018 [27]

Berr et al. 2015 [28]

Romanholi et al. 2008 [128], Valero et al. 2004 [129], Vassiliadi et al.2016 [130], Losa et al. 2009 [131], L Marc'hadour et al. 2015 [132], Barbot et al. 2013 [133], Losa et al. 2001 [134], Cambos et al. 2020 [42]

van Aken et al. 1997 [135]

Uvelius et al. 2018 [136] of BMI after treatment were factors that were associated with remission [26]. Furthermore, recurrence is also influenced by the presence of somatic USP8 mutations and is significantly more frequent in patients with USP8 mutant corticotroph tumors [27]. Duration of symptoms until first surgery does not influence remission rate [28]. Another matter of debate are patients in whom a corticotroph pituitary adenoma is not identified histologically. In a study by Pouratian, an adenoma could not be confirmed by pathology in 111 out of 490 cases. Of these patients, only $50 \%$ achieved remission compared with $88 \%$ of patients with histologically confirmed adenoma [29]. Furthermore, these patients had higher rates of early recurrence within the first months after surgery [29]. In another study focusing on the pathology, recurrence was associated with the lack of peritumoral Crooke's change [30] but this finding was not confirmed in a larger study [31]. However, it should be kept in mind that rate of diagnostic errors (misdiagnoses) in pathology ranges between 3-9\% [32] and, therefore, falsenegative and false-positive results are not uncommon. In a meta-analysis by Roelfsema, only postoperative hormone levels remained a prognostic factor for remission - as shown in 20 studies-while other factors such as age, gender, tumor size, and invasion were unrelated to recurrence [2].

\section{Diagnosis of recurrence}

\section{Surveillance of patients in remission: how often performing follow-up studies?}

It is a widely accepted practice to recommend screening of patients with a history of CD on a regular basis. The rational, as outlined above, is the lack of a reliable prediction model as no single or combined clinical or biochemical parameter can exclude future recurrence with acceptable precision $[33,34]$. Currently, there is no consensus recommendation on the intervals of clinical and/or biochemical follow-up. Ayala et al. recommend to screen patients in different intervals - 3 months to annually-depending on morning serum cortisol levels measured 2-3 days post-surgery [9]. Fleseriu et al. recommend to evaluate patients clinically on an annual basis [34] and to conduct a biochemical screening when the patient has new evidence of a tumor in the MRI or 
worsening/onset of symptoms and comorbidities that might be related to CS [34]. In an expert statement, Geer et al. suggested a complex and detailed scheme, taking into account the time passed since pituitary surgery, the requirement for steroid replacement therapy, and previous clinical and biochemical evidence of remission [35]. Suggested test intervals vary between 2 and 6 months. The overarching premises of these quite different recommendations is patient safety and cost effectiveness, within the frame of different health care systems. An additional factor to be considered is that close surveillance of patients can have a negative impact on well-being, similar to cancer patients who are reminded every time at posttreatment staging on their cancer history. As the vast majority all of recurrences occur in the first 10 years after pituitary surgery as shown in the meta-analysis by Roelfsema [2], we recommend as an minimum compromise an annual screening of patients with CD in the first 10 years after surgery. A study by Psaras et al. with 33 patients with CD revealed that $84.5 \%$ are followed-up by endocrinologists and only $9.1 \%$ of patients are not under aftercare at all, which is all in all satisfying but leaves room for improvement [36].

\section{Are there data on clinical evidence of recurrence in CD?}

While there are different studies focusing on the biochemical recurrence of $\mathrm{CD}$, the clinical course has seldom been addressed by studies-and never as a sole parameter but always in combination with biochemical results [4]. Therefore, questions remain, i.e., whether there is a certain sequence of events in which signs and symptoms recur. Studies addressing these aspects might be of value regarding treatment and screening decisions. The lack of studies addressing this topic is surprising when considering that there is still a debate on how to define recurrence biochemically [37].

\section{Biochemical evidence for recurrence}

Diagnosis of recurrence is comparable to the diagnostic process at first diagnosis. Biochemical screening consists of the LDDST, the late-night salivary cortisol and the cortisol in a $24 \mathrm{~h}$ collection (UFC). In addition, a distinct increase of plasma ACTH can be helpful to further support the presence of recurrence. Of these tests, midnight salivary cortisol is the first test to become abnormal [38, 39], followed by LDDST, while UFC appears to be least sensitive [12], most likely because of the use of immunoassays with inappropriately wide normal ranges and unspecified cross-reactivity of the primary antibody with other steroids. However, in a study with 38 patients by Castinetti, a combined dexamethasone desmopressin test was an early marker for recurrence before other tests showed abnormal results [40]. The test was conducted 6 and 12 months after surgery and after that yearly. Similarly, Ambrogio et al. showed that the desmopressin test might be helpful to detect recurrence early [41]. In this study, desmopressin test was performed immediately after surgery ( $<1$ week) and in the follow-ups (after a few months and yearly). A recent study reported that a cortisol response during the desmopressin test, performed in the first 3 month of the postoperative phase of hypocortisolism, might be quite predictive [42].

In a study by Atkinson et al., a significant number of patients had recurrence with cyclic hypercortisolism, suggesting that repetitive measurements of urine and salivary samples are crucial [6]. Further diagnostic subtyping, such as $\mathrm{CRH}$ stimulation test, the high-dose dexamethasone suppression test, or inferior sinus petrosal sampling is per se not required because the origin of hypercortisolism, based on positive histopathology and/or postoperative tertiary adrenal insufficiency, is obvious. Exceptions may be the rare case of cyclic CS of unknown origin in which the switch to 'off' phase' coincided with the time of pituitary surgery, causing a diagnostic riddle.

\section{Imaging to detect recurrence}

Failure to identify the tumor pre-surgery by MRI is associated with a higher rate of persistence and recurrence in several studies [7, 21]. A similar scenario should apply to patients with negative MRI at recurrence although no study has reported MRI positivity rates in the recurrence situation. It can be assumed that the adenoma should be located on the same side as initially [43]; in a study by Hofmann et al., the recurrent adenoma was always located on the same side as initially [44]. An inferior petrosal sampling can be helpful [15] to identify the location of the coricotroph adenoma (right or left)_at least in 70\% of cases [45] in the setting of first surgery. However, there is no consensus whether to use inferior petrosal sampling solely for this purpose, and postoperative changes in venous anatomy may further reduce its value.

In a review by Vitale et al. the authors recommended to use three Tesla MRI in patients with negative standard 1.5 Tesla MRI and to use an optimized MRI protocol [46]. In a recent study with 23 patients with $\mathrm{CD}$ and a negative standard MRI, the combination of post-contrast FLAIR sequences and post-contrast 3D-GRE sequences was helpful in otherwise pre-operative undetectable microadenomas [47], as all five adenomas invisible by standard MRI were detectable by post-contrast FLAIR sequences. Grober et al. conducted a study with different MRI techniques to detect microadenoma, showing that a spoiled-gradient echo 3D T1 sequence has a higher sensitivity than dynamic contrast-enhanced MRIs and conventional MRI in surgery-naïve patients [48]. 
New imaging technologies such as the combination of MRI and PET were recently studied in 35 patients with therapy- naïve CD. While diagnostic accuracy using MRI was only $40 \%$, the adenoma could be detected with the combination of methionine-PET/3.0 Tesla MRI in $100 \%$ of cases and with FDG-PET/3.0 Tesla MRI in 73\% of cases [49]. The value of methionine PET-imaging to detect adenomas was also shown in another study with smaller sample size [50]. As shown in a different study, simultaneously CRH stimulation may improve the detection rate of adenomas by FDG-PET [51]. Unfortunately, there are no studies exclusively focusing on patients with recurrent disease.

\section{Treatment options after recurrence and in persistent Cushing's syndrome}

\section{Persistency versus recurrence}

Treatment options in both scenarios are comparable with only little differences (overview: Fig. 1, Table 3). In persistent disease, it might be necessary to repeat or add

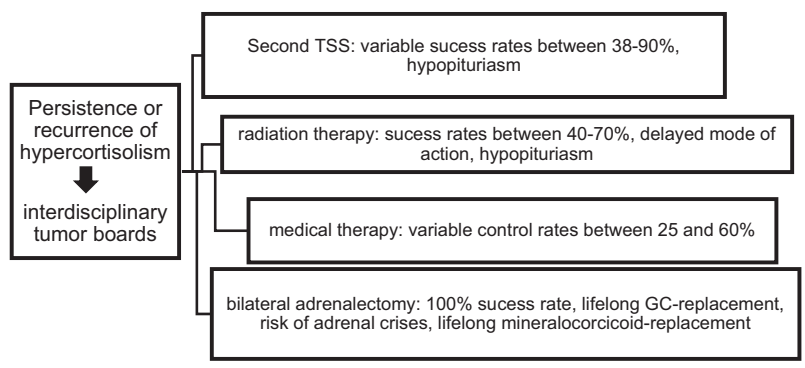

Fig. 1 Treatment options after recurrence [93] diagnostic tests such as the inferior sinus petrosus sampling or to conduct further imaging to exclude an ectopic CS definitely. Furthermore, while a second pituitary surgery is normally the first treatment option in recurrent $\mathrm{CD}$, it might not be in persistent $C D$ with invasive growth of the adenoma. In these cases, when a complete removal of the tumor by surgery is unlikely, radiation therapy might be a more preferable option.

\section{Second pituitary surgery (TSS)}

The value of a second pituitary surgery was already shown in 1989 by Friedman et al. [52]. It has to be differentiated between a second TSS performed shortly after first TSS in persistent disease and a second TSS in recurrent disease. In persistent disease, the surgery is usually performed early (days to 4 weeks) before scar tissue has been developing [53]. Remission rate in persistent disease is about $54 \%$ while remission rates are higher $(64 \%)$ in recurrent disease. A thorough review of outcomes in persistent versus recurrent $\mathrm{CD}$ can be found in Rubinstein et al. [54]. Pituitary surgery should be conducted in a center with high experience (more than 25 surgeries per year [55]) — this applies both for persistent, recurrent, and surgery-naïve CD as well. A second pituitary surgery seems to be currently the firstline therapy in recurrent $\mathrm{CD}$ with a mean remission rate of $64 \%$, but high rates of variability $(38-90 \%)$ is reported in the literature [54]. Success rates seem to be lower than in first surgery [56]. Second TSS has more complication due to scar tissue in the pituitary. The risk of hypopituitarism is higher due to a more aggressive surgery [57], with incidences between 19 [58] and 64\% [59].

Table 3 Advantages and disadvantages of different treatment options

\begin{tabular}{|c|c|c|c|}
\hline Therapy & Advantages & Disadvantages & Success rates \\
\hline $\begin{array}{l}\text { Second or third pituitary } \\
\text { surgery }\end{array}$ & $\begin{array}{l}\text { - Safe to perform when conducted by } \\
\text { an experienced surgeon }\end{array}$ & $\begin{array}{l}\text { - Hypopituriarism } \\
\text { - Recurrence possible } \\
\text { - Very variable success rates } \\
\text { - Risk of surgery }\end{array}$ & Mean $64 \%(38-90 \%)$ \\
\hline Radiation therapy & $\begin{array}{l}\text { - Can be performed in patients that } \\
\text { are not suitable candidates for } \\
\text { surgery }\end{array}$ & $\begin{array}{l}\text { - Hypopituitarism } \\
\text { - Recurrence possible } \\
\text { - Delayed mode of action; combination } \\
\text { with medical therapy mandatory } \\
\text { - Several treatment sessions in } \\
\text { unfractionated radiation therapy }\end{array}$ & $40-70 \%[137]$ \\
\hline Medical therapy & $\begin{array}{l}\text { - Can be performed in patients that } \\
\text { are not suitable candidates for } \\
\text { surgery } \\
\text { - Bridge-therapy } \\
\text { - Acute onset }\end{array}$ & $\begin{array}{l}\text { - Side effects } \\
\text { - Escape possible } \\
\text { - High costs over the long term }\end{array}$ & $\begin{array}{l}25-60 \% \text { (dependent on drug) } \\
\text { [137], up to } 82 \% \text { for mitotane [75] }\end{array}$ \\
\hline Bilateral adrenalectomy & $\begin{array}{l}\text { - Definitive therapy } \\
\text { - } 100 \% \text { success rate }\end{array}$ & $\begin{array}{l}\text { - Life-long adrenal insufficiency, } \\
\text { patients are at risk of addison's crisis } \\
\text { - Risk of Nelson Tumor } \\
\text { - Risk of surgery }\end{array}$ & $100 \%$ \\
\hline
\end{tabular}




\section{Radiation therapy}

Radiation therapy can be conducted as conventional radiotherapy (fractionized over 25-30 sessions) or as stereotactic (unfractionated, single-dose) radiosurgery. In case of a negative MRI scan, radiosurgery should be delivered to the area of the adenoma at time of first diagnosis, while radiotherapy is delivered in this scenario to the region of the whole pituitary.

Radiotherapy is a valid therapeutic option, with median remission rates of $80 \%$ (123 patients in 7 studies), no recurrence rate and a median time to remission of 8 months [60]. However, cabergoline must not be used during radiotherapy, as it may increases recurrence rate due to a recently published study [61]. New hypopituitarism is a common problem in up to 38 [62]-40\% of patients [63]. Other severe side effects are rare (optic neuropathy, radiation induced second tumors) [64] and the 10 year survival rate was very high with $95 \%$ in one study [64]. Response to radiotherapy does not correlate with sex, age, or severity of disease [65].

Stereotactic radiosurgery was introduced in Sweden in 1969 by Lars Leksell but was not widespread used to treat ACTH-producing adenomas in other countries until the 1980s [66]. Success of this treatment options depends on the size and location of the tumor. Obviously, best results are achieved in well-defined tumors [67]. Published remission rates are slightly lower than for fractionized radiotherapy: In a retrospective study with 68 patients, gamma knife radiosurgery turned out to be quite effective, leading to remission in $76 \%$ of patients within the next 5 years. Escape rate following radiosurgery was $13 \%$, and $23 \%$ of patients suffered from new pituitary deficiencies [68]. Another study with 43 patients reported a remission rate of $63 \%$ [69]. A higher escape rate of $18 \%$ was reported in an international, multicenter study with 278 patients [70]. Forty-two percent of patients developed new hypopituitarism when stereotactic proton radiosurgery was used [71]. Remission rate using Cyberknife were lower in one study, reporting a remission rate of $57 \%$, but the study population was very small (seven patients) and patients had CD with sinus cavernosus invasion [72]. Severe side effects with transient visual loss and permanent diplopia were seen in 2 out of 20 patients in another study [73]. Importantly, experience of the center is associated with remission rate [74].

The main disadvantage of radiation therapy is the relatively long time to remission. A combination with medical therapy is always required to bridge the time between radiation and remission. Effective medical control should be proven before initiation of radiation therapy. Continuous endocrine surveillance is mandatory to detect hypopituitarism early and also to adjust medical treatment.

\section{Medical therapy}

Medical therapy can be used short-term but is also suitable for long-term control. Side effects are specific for each drug (Table 4). Medical therapy is pituitary-directed (pasireotide and cabergoline), adrenal-directed (steroidogenesis inhibitors metyrapone, ketoconazole, mitotane and etomidate) and glucocorticoid-receptor directed (mifepristone), the last one currently not being approved in Europe. Efficacy of all drugs is quite variable; it is very high for steroidogenesis inhibitors and mifepristone, but lower for pasireotide and cabergoline [75]. Medical therapy can either be conducted as monotherapy or in combination with radiation therapy. Many drugs may be combined with each other; treatment can be performed as a block-and-replace-strategy or by titration of the drugs. Pituitary-directed medical therapy is reserved for $\mathrm{CD}$ while all the other drugs can be given in all forms of CS. Pasireotide is more effective in patients with mild or moderate hypercortisolism, with urinary free cortisol levels of up to two-times the normal range reaching control rates in $\sim 40 \%$ [76]. Pasireotide treatment also leads to reduction of tumor volume [77]. Cabergoline is effective in up to $40 \%$ of patients, but $22 \%$ of patients escaped from remission over the long-term [78]. Adrenal steroidogenesis inhibitors block one or more enzymes in the steroidogenesis pathway. Glucocorticoid receptor blockers reduce the activity of cortisol on the glucocorticoid receptor. Advantages of medical therapy include the lower risk for adrenal insufficiency than by surgery and no risk for hypopituitarism. They are relatively safe to us if administered correctly. As their effect is immediate, they are the first choice in emergency situations with severe hypercortisolism. Medical therapy is also an option for patients who are no suitable candidates for surgery due to comorbidities. Disadvantages include the side effects of the medication, the high costs when used over a long-time period and the fact, that it is not a definite therapy. Furthermore, escape phenomena are possible (though seldom) leading to a recurrence of hypercortisolism.

New adrenal steroidogenesis blockers and glucocorticoid receptor blockers such as osilodrostat [79], levoketoconazole [80], or relacorilant [81] are currently tested in phase II and phase III studies. There are also trials on new pituitarydirected drugs (for example retinoic acid) [82].

Although medical therapy can lower cortisol levels, according to a recent meta-analysis data regarding the clinical improvement or quality of life in patients treated with medical therapy are rare [75]. Also, it is unclear if medical therapy has different effects in patients with therapy-naïve $\mathrm{CD}$ or in patients with recurrent $\mathrm{CD}$. 


\section{Bilateral adrenalectomy}

Bilateral adrenalectomy is considered as an emergency option in severe and uncontrolled hypercortisolism [83] or as a last option, when other treatment options are unsuccessful or not well-tolerated. Bilateral adrenalectomy is a definitive therapy with a success rate of $100 \%$. In a recent metanalysis, it has been shown that besides being a safe treatment option with a surgical mortality of $3 \%$ [84], it also improves comorbidities and leads to an improvement of health-related quality of life [85]. The reasons why bilateral adrenalectomy is considered ultima ratio, are Nelson's syndrome and permanent adrenal insufficiency. Nelson's syndrome develops with a prevalence between 8 and 29\% in studies with patient populations over 40 years [86]. Nelson's syndrome, defined as cortisotroph tumor progression, is diagnosed by elevated plasma ACTH levels, hyperpigmentation, and tumor growth [87]. One study suggests that Nelson's syndrome can be prevented by a prophylactic radiation therapy [88] but evidence for this approach is low, so it is not officially recommended. A hypophysectomy is seldom required [88]. The need for lifelong hydrocortisone and fludrocortisone replacement therapy with the risk of having adrenal crises is the other main disadvantage of bilateral adrenalectomy.

\section{Treatment recommendations in biochemical and clinical mild recurrence}

In patients with very mild hypercortisolism and no clinical signs of active CS, a wait and watch strategy can be practiced if there remain doubts on a recurrence. However, as known from patients with subclinical adrenal CS, cardiovascular outcome can be negatively influenced even by mild hypercortisolism [89]. Based on our clinical experience, we highly recommend to start treatment early in recurrent disease to improve both quality of life and long-term outcome.

Carroll et al. showed in a study with 15 patients that patients benefit from early initiation of second-line treatments in terms of weight-loss, improvement of hypertension and $\mathrm{Hba1c}$, and improved quality of life, respectively. Of the 15 patients, 12 had normal UFC at time of recurrence, whereas the $1 \mathrm{mg}$ dexamethasone suppression test was abnormal in 11 of 15 , and 14 had abnormal late night salivary cortisol levels [90].

Keeping this in mind, we recommend to start treatment in these patients early, for example with low dose metyrapone, ketoconazole, or pasireotide in patients with negative MRI. Treatment with pasireotide might be a treatment option in patients with mild hypercortisolism [76] since success rate depends on the degree of hypercortisolism. In patients with a positive MRI, a second pituitary surgery 
should be considered early on. Comorbidities such as diabetes, arterial hypertension, and osteoporosis should always be treated adequately in parallel. Also, depression elevates the risk of cardiovascular diseases [91] and should be treated.

\section{Special remarks on recurrence of CD during pandemics}

Due to an expert consensus, diagnosis and treatment of recurrent $\mathrm{CD}$ must not be delayed due to pandemic crisis such as the currently worldwide COVID-19-Crisis. On the other hand-as patients with $\mathrm{CD}$ are immunocompromised and at risk of infections-alternative consultation ways such as video and telephone might be used. Strict adherence to social distancing recommendations are highly recommended. Furthermore, medical treatment might be the first-line therapy in this scenario as treatment should not be delayed by extensive diagnostic procedures, however, hypercortisolism should be controlled as soon as possible [92].

\section{Overall recommendations: expertize and interdisciplinary tumor boards}

Patients benefit from treatment by an experienced endocrinologist and neurosurgeon; the same applies for the diagnostic process and treatment decisions. As CD is a rare and complex disease, we highly recommend that patients should be treated in an experienced center that is specialized in CS. For treatment decisions, interdisciplinary tumor board have proven their worth.

\section{Summary and conclusion}

Recurrence is a common problem in patients with $\mathrm{CD}$ occurring in around $15 \%$ of patients. The time to relapse varies between 3 and 158 months (mean 51 months), and $50 \%$ of relapses occur during the first 50 months after initial surgery. Annual clinical screening is recommended. In case of clinical and biochemical evidence of recurrence, comorbidities should be immediately treated and the best option for secondary treatment should be selected. This decision requires a high level of expertize and transfer of the patient to a tertiary center is highly advised. If second TSS, radiation therapy or long-term medical therapy are no options, bilateral adrenalectomy is indicated with immediate control of hypercortisolism and improved long-term outcome.

Acknowledgements Open Access funding provided by Projekt DEAL.
Author contributions L.B. performed the literature search and the drafting of the paper. M.R. contributed to the literature search and the drafting of the paper. All other authors substantially contributed to the critical revision of the paper. All authors approved the final version for submission.

\section{Compliance with ethical standards}

Conflict of interest The authors declare that they have no conflict of interest.

Publisher's note Springer Nature remains neutral with regard to jurisdictional claims in published maps and institutional affiliations.

Open Access This article is licensed under a Creative Commons Attribution 4.0 International License, which permits use, sharing, adaptation, distribution and reproduction in any medium or format, as long as you give appropriate credit to the original author(s) and the source, provide a link to the Creative Commons license, and indicate if changes were made. The images or other third party material in this article are included in the article's Creative Commons license, unless indicated otherwise in a credit line to the material. If material is not included in the article's Creative Commons license and your intended use is not permitted by statutory regulation or exceeds the permitted use, you will need to obtain permission directly from the copyright holder. To view a copy of this license, visit http://creativecommons. org/licenses/by/4.0/.

\section{References}

1. J. Newell-Price, X. Bertagna, A.B. Grossman, L.K. Nieman, Cushing's syndrome. Lancet (London, England) 367(9522), 1605-1617 (2006). https://doi.org/10.1016/s0140-6736(06)68699-6

2. F. Roelfsema, N.R. Biermasz, A.M. Pereira, Clinical factors involved in the recurrence of pituitary adenomas after surgical remission: a structured review and meta-analysis. Pituitary 15(1), 71-83 (2012). https://doi.org/10.1007/s11102-011-0347-7

3. L.H.A. Broersen, N.R. Biermasz, W.R. van Furth, F. de Vries, M.J.T. Verstegen, O.M. Dekkers, A.M. Pereira, Endoscopic vs. microscopic transsphenoidal surgery for Cushing's disease: a systematic review and meta-analysis. Pituitary 21(5), 524-534 (2018). https://doi.org/10.1007/s11102-018-0893-3

4. S. Petersenn, A. Beckers, D. Ferone, A. van der Lely, J. Bollerslev, M. Boscaro, T. Brue, P. Bruzzi, F.F. Casanueva, P. Chanson, A. Colao, M. Reincke, G. Stalla, S. Tsagarakis, Therapy of endocrine disease: outcomes in patients with Cushing's disease undergoing transsphenoidal surgery: systematic review assessing criteria used to define remission and recurrence. Eur J Endocrinol. 172(6), R227-R239 (2015). https://doi.org/10. 1530/eje-14-0883

5. F. Esposito, J.R. Dusick, P. Cohan, P. Moftakhar, D. McArthur, C. Wang, R.S. Swerdloff, D.F. Kelly, Clinical review: early morning cortisol levels as a predictor of remission after transsphenoidal surgery for Cushing's disease. J. Clin. Endocrinol. Metab. 91(1), 7-13 (2006). https://doi.org/10.1210/jc.2005-1204

6. A.B. Atkinson, A. Kennedy, M.I. Wiggam, D.R. McCance, B. Sheridan, Long-term remission rates after pituitary surgery for Cushing's disease: the need for long-term surveillance. Clin. Endocrinol. 63(5), 549-559 (2005). https://doi.org/10.1111/j. 1365-2265.2005.02380.x

7. D. Bochicchio, M. Losa, M. Buchfelder, Factors influencing the immediate and late outcome of Cushing's disease treated by 
transsphenoidal surgery: a retrospective study by the European Cushing's Disease Survey Group. J. Clin. Endocrinol. Metab. 80 (11), 3114-3120 (1995). https://doi.org/10.1210/jcem.80.11. 7593411

8. P. Abellán Galiana, C. Fajardo Montañana, P.A. Riesgo Suárez, J. Gómez Vela, C.M. Escrivá, V.R. Lillo, [Predictors of longterm remission after transsphenoidal surgery in Cushing's disease]. Endocrinol. Nut. 60(8), 475-482 (2013). https://doi.org/ 10.1016/j.endonu.2012.09.009

9. A. Ayala, A.J. Manzano, Detection of recurrent Cushing's disease: proposal for standardized patient monitoring following transsphenoidal surgery. J Neuro-oncol. 119(2), 235-242 (2014). https://doi.org/10.1007/s11060-014-1508-0

10. R.A. Feelders, S.J. Pulgar, A. Kempel, A.M. Pereira, The burden of Cushing's disease: clinical and health-related quality of life aspects. Eur. J Endocrinol. 167(3), 311-326 (2012). https://doi. org/10.1530/eje-11-1095

11. N. Hameed, C.G. Yedinak, J. Brzana, S.H. Gultekin, N.D. Coppa, A. Dogan, J.B. Delashaw, M. Fleseriu, Remission rate after transsphenoidal surgery in patients with pathologically confirmed Cushing's disease, the role of cortisol, ACTH assessment and immediate reoperation: a large single center experience. Pituitary 16(4), 452-458 (2013). https://doi.org/10. 1007/s11102-012-0455-Z

12. J.M. Hinojosa-Amaya, E.V. Varlamov, S. McCartney, M. Fleseriu, Hypercortisolemia recurrence in cushing's disease; a diagnostic challenge. Front. Endocrinol. 10, 740-740 (2019). https://doi.org/10.3389/fendo.2019.00740

13. A.H. Tahir, L.R. Sheeler, Recurrent Cushing's disease after transsphenoidal surgery. Arch. Intern. Med. 152(5), 977-981 (1992)

14. E. Fomekong, D. Maiter, C. Grandin, C. Raftopoulos, Outcome of transsphenoidal surgery for Cushing's disease: a high remission rate in ACTH-secreting macroadenomas. Clin. Neurol. Neurosurg. 111(5), 442-449 (2009). https://doi.org/10.1016/j. clineuro.2008.12.011

15. S. Yamada, N. Fukuhara, H. Nishioka, A. Takeshita, N. Inoshita, J. Ito, Y. Takeuchi, Surgical management and outcomes in patients with Cushing disease with negative pituitary magnetic resonance imaging. World Neurosurg. 77(3-4), 525-532 (2012). https://doi.org/10.1016/j.wneu.2011.06.033

16. N.M. Albiger, C.M. Scaroni, F. Mantero, Cyclic Cushing's syndrome: an overview. Arq. Brasileiros de Endocrinol. e Metabologia 51(8), 1253-1260 (2007). https://doi.org/10.1590/ s0004-27302007000800011

17. E.B. Geer, I. Shafiq, M.B. Gordon, V. Bonert, A. Ayala, R.S. Swerdloff, L. Katznelson, Y. Lalazar, E. Manuylova, K.J. Pulaski-Liebert, J.D. Carmichael, Z. Hannoush, V. Surampudi, M.S. Broder, D. Cherepanov, M. Eagan, J. Lee, Q. Said, M.P. Neary, B.M.K. Biller, Biochemical control during long-term follow-up of 230 adult patients with Cushing Disease: a multicenter retrospective study. Endocr. Pract. 23(8), 962-970 (2017). https://doi.org/10.4158/EP171787.OR

18. C. Brichard, E. Costa, E. Fomekong, D. Maiter, C. Raftopoulos, Outcome of transsphenoidal surgery for cushing disease: a single-center experience over 20 Years. World Neurosurg. 119, e106-e117 (2018). https://doi.org/10.1016/j.wneu.2018.07.055

19. A.M. Abu Dabrh, N.M. Singh Ospina, A. Al Nofal, W.H. Farah, P. Barrionuevo, M. Sarigianni, A.B. Mohabbat, K. Benkhadra, B.G. Carranza Leon, M.R. Gionfriddo, Z. Wang, K. Mohammed, A.T. Ahmed, T.A. Elraiyah, Q. Haydour, F. Alahdab, L.J. Prokop, M.H. Murad, Predictors of biochemical remission and recurrence after surgical and radiation treatments of Cushing disease: a systematic review and meta-analysis. Endocr. Pract. 22 (4), 466-475 (2016). https://doi.org/10.4158/ep15922.ra

20. F.G. Barker 2nd, A. Klibanski, B. Swearingen, Transsphenoidal surgery for pituitary tumors in the United States, 1996-2000: mortality, morbidity, and the effects of hospital and surgeon volume. J. Clin. Endocrinol. Metab. 88(10), 4709-4719 (2003). https://doi.org/10.1210/jc.2003-030461

21. G.H. Chee, D.B. Mathias, R.A. James, P. Kendall-Taylor, Transsphenoidal pituitary surgery in Cushing's disease: can we predict outcome? Clin. Endocrinol. 54(5), 617-626 (2001). https://doi.org/10.1046/j.1365-2265.2001.01261.x

22. J. Ramm-Pettersen, H. Halvorsen, J.A. Evang, P. Rønning, P.K. Hol, J. Bollerslev, J. Berg-Johnsen, E. Helseth, Low immediate postoperative serum-cortisol nadir predicts the short-term, but not long-term, remission after pituitary surgery for Cushing's disease. BMC Endocr. Disord. 15, 62 (2015). https://doi.org/10. 1186/s12902-015-0055-9

23. L.B. Yap, H.E. Turner, C.B. Adams, J.A. Wass, Undetectable postoperative cortisol does not always predict long-term remission in Cushing's disease: a single centre audit. Clin. Endocrinol. 56(1), 25-31 (2002). https://doi.org/10.1046/j.0300-0664.2001. 01444.x

24. A.M. Pereira, M.O. van Aken, H. van Dulken, P.J. Schutte, N.R. Biermasz, J.W. Smit, F. Roelfsema, J.A. Romijn, Long-term predictive value of postsurgical cortisol concentrations for cure and risk of recurrence in Cushing's disease. J. Clin. Endocrinol. Metab. 88(12), 5858-5864 (2003). https://doi.org/10.1210/jc.2003-030751

25. Y. Liu, X. Liu, X. Hong, P. Liu, X. Bao, Y. Yao, B. Xing, Y. Li, Y. Huang, H. Zhu, L. Lu, R. Wang, M. Feng, Prediction of recurrence after transsphenoidal surgery for cushing's disease: the use of machine learning algorithms. Neuroendocrinology 108 (3), 201-210 (2019). https://doi.org/10.1159/000496753

26. C.-H. Kuo, S.-R. Shih, H.-Y. Li, S.-C. Chen, P.-J. Hung, F.-Y. Tseng, T.-C. Chang, Adrenocorticotropic hormone levels before treatment predict recurrence of Cushing's disease. J. Formos Med. Assoc. 116(6), 441-447 (2017). https://doi.org/10.1016/j. jfma.2016.08.008

27. A. Albani, L.G. Perez-Rivas, C. Dimopoulou, S. Zopp, P. ColonBolea, S. Roeber, J. Honegger, J. Flitsch, W. Rachinger, M. Buchfelder, G.K. Stalla, J. Herms, M. Reincke, M. Theodoropoulou, The USP8 mutational status may predict long-term remission in patients with Cushing's disease. Clin. Endocrinol. (2018). https://doi.org/10.1111/cen.13802

28. C.M. Berr, G. Di Dalmazi, A. Osswald, K. Ritzel, M. Bidlingmaier, L.L. Geyer, M. Treitl, K. Hallfeldt, W. Rachinger, N. Reisch, R. Blaser, J. Schopohl, F. Beuschlein, M. Reincke, Time to recovery of adrenal function after curative surgery for Cushing's syndrome depends on etiology. J. Clin. Endocrinol. Metab. 100(4), 1300-1308 (2015). https://doi.org/10.1210/jc.2014-3632

29. N. Pouratian, D.M. Prevedello, J. Jagannathan, M.B. Lopes, M. L. Vance, E.R. Laws Jr, Outcomes and management of patients with Cushing's disease without pathological confirmation of tumor resection after transsphenoidal surgery. J. Clin. Endocrinol. Metab. 92(9), 3383-3388 (2007). https://doi.org/10.1210/jc. 2007-0208

30. K. Hague, K.D. Post, S. Morgello, Absence of peritumoral Crooke's change is associated with recurrence in surgically treated Cushing's disease. Surg. Neurol. 53(1), 77-81 (2000)

31. D. Cordeiro, Z. Xu, M. Nasser, B. Lopes, M.L. Vance, J. Sheehan, The role of Crooke's changes in recurrence and remission after gamma knife radiosurgery. J. Neuro-oncol. 142(1), 171-181 (2019). https://doi.org/10.1007/s11060-018-03078-8

32. M. Peck, D. Moffat, B. Latham, T. Badrick, Review of diagnostic error in anatomical pathology and the role and value of second opinions in error prevention. J. Clin. Pathol. 71(11), 995-1000 (2018). https://doi.org/10.1136/jclinpath-2018-205226

33. I. Huguet, G. Ntali, A. Grossman, N. Karavitaki, Cushing's disease - quality of life, recurrence and long-term morbidity. Eur. Endocrinol. 11(1), 34-38 (2015). https://doi.org/10.17925/ee. 2015.11.01.34 
34. M. Fleseriu, A.H. Hamrahian, A.R. Hoffman, D.F. Kelly, L. Katznelson, American association of clinical endocrinologists and American college of endocrinology disease state clinical review: diagnosis of recurrence in Cushing disease. Endocr. Pract. 22(12), 1436-1448 (2016). https://doi.org/10.4158/ep161512.dscr

35. E.B. Geer, A. Ayala, V. Bonert, J.D. Carmichael, M.B. Gordon, L. Katznelson, E. Manuylova, I. Shafiq, V. Surampudi, R.S. Swerdloff, M.S. Broder, D. Cherepanov, M. Eagan, J. Lee, Q. Said, M.P. Neary, B.M.K. Biller, Follow-up intervals in patients with Cushing's disease: recommendations from a panel of experienced pituitary clinicians. Pituitary 20(4), 422-429 (2017). https://doi.org/10.1007/s11102-017-0801-2

36. T. Psaras, M. Milian, V. Hattermann, B. Gallwitz, T. Freiman, J. Honegger, Aftercare in patients with Cushing's disease and acromegaly: is there room for improvement? Acta Neurochirurgica 152 (2), 271-278 (2010). https://doi.org/10.1007/s00701-009-0544-6

37. N.K. Sundaram, A. Carluccio, E.B. Geer, Characterization of persistent and recurrent Cushing's disease. Pituitary 17(4), 381-391 (2014). https://doi.org/10.1007/s11102-013-0511-3

38. M. Danet-Lamasou, J. Asselineau, P. Perez, A. Vivot, M.L. Nunes, H. Loiseau, F. San-Galli, B. Cherifi-Gatta, J.B. Corcuff, A. Tabarin, Accuracy of repeated measurements of late-night salivary cortisol to screen for early-stage recurrence of Cushing's disease following pituitary surgery. Clin. Endocrinol. 82(2), 260-266 (2015). https://doi.org/10.1111/cen.12534

39. F.G. Amlashi, B. Swearingen, A.T. Faje, L.B. Nachtigall, K.K. Miller, A. Klibanski, B.M. Biller, N.A. Tritos, Accuracy of latenight salivary cortisol in evaluating postoperative remission and recurrence in cushing's disease. J. Clin. Endocrinol. Metab. 100 (10), 3770-3777 (2015). https://doi.org/10.1210/jc.2015-2107

40. F. Castinetti, M. Martinie, I. Morange, H. Dufour, N. Sturm, J.G. Passagia, B. Conte-Devolx, O. Chabre, T. Brue, A combined dexamethasone desmopressin test as an early marker of postsurgical recurrence in Cushing's disease. J. Clin. Endocrinol. Metab. 94(6), 1897-1903 (2009)

41. A.G. Ambrogio, M. Andrioli, M. De Martin, F. Cavagnini, F. Pecori Giraldi, Usefulness of desmopressin testing to predict relapse during long-term follow-up in patients in remission from Cushing's disease. Endocr. Connect. 6(8), 791-799 (2017). https://doi.org/10.1530/ec-17-0292

42. S. Cambos, K. Mohammedi, F. Castinetti, C. Saie, J. Young, P. Chanson, A. Tabarin, Persistent cortisol response to desmopressin predicts recurrence of Cushing's disease in patients with post-operative corticotropic insufficiency. Eur. J. Endocrinol 182 (5), 489-498 (2020). https://doi.org/10.1530/eje-19-0770

43. R.D. Dickerman, E.H. Oldfield, Basis of persistent and recurrent Cushing disease: an analysis of findings at repeated pituitary surgery. J. Neurosurg. 97(6), 1343-1349 (2002). https://doi.org/ 10.3171/jns.2002.97.6.1343

44. B.M. Hofmann, M. Hlavac, J. Kreutzer, G. Grabenbauer, R. Fahlbusch, Surgical treatment of recurrent Cushing's disease. Neurosurgery 58(6), 1108-1118 (2006). https://doi.org/10.1227/ 01.neu.0000215945.26764.92. discussion 1108-1118

45. F.S. Bonelli, J. Huston 3rd, P.C. Carpenter, D. Erickson, W.F. Young Jr., F.B. Meyer, Adrenocorticotropic hormone-dependent Cushing's syndrome: sensitivity and specificity of inferior petrosal sinus sampling. Am. J. Neuroradiol. 21(4), 690-696 (2000)

46. G. Vitale, F. Tortora, R. Baldelli, F. Cocchiara, R.M. Paragliola, E. Sbardella, C. Simeoli, F. Caranci, R. Pivonello, A. Colao, Pituitary magnetic resonance imaging in Cushing's disease. Endocrine $\mathbf{5 5}$ (3), 691-696 (2017). https://doi.org/10.1007/s12020-016-1038-y

47. G.P. Chatain, N. Patronas, J.G. Smirniotopoulos, M. Piazza, S. Benzo, A. Ray-Chaudhury, S. Sharma, M. Lodish, L. Nieman, C. A. Stratakis, P. Chittiboina, Potential utility of FLAIR in MRInegative Cushing's disease. J. Neurosurg. 129(3), 620-628 (2018). https://doi.org/10.3171/2017.4.jns17234
48. Y. Grober, H. Grober, M. Wintermark, J.A. Jane, E.H. Oldfield, Comparison of MRI techniques for detecting microadenomas in Cushing's disease. J. Neurosurg. 128(4), 1051-1057 (2018). https://doi.org/10.3171/2017.3.jns163122

49. H. Ikeda, T. Abe, K. Watanabe, Usefulness of composite methionine-positron emission tomography/3.0-tesla magnetic resonance imaging to detect the localization and extent of earlystage Cushing adenoma. J. Neurosurg. 112(4), 750-755 (2010). https://doi.org/10.3171/2009.7.jns09285

50. O. Koulouri, A. Steuwe, D. Gillett, A.C. Hoole, A.S. Powlson, N.A. Donnelly, N.G. Burnet, N.M. Antoun, H. Cheow, R.J. Mannion, J.D. Pickard, M. Gurnell, A role for 11C-methionine PET imaging in ACTH-dependent Cushing's syndrome. Eur. J. Endocrinol. 173(4), M107-M120 (2015). https://doi.org/10. 1530/eje-15-0616

51. J. Boyle, N.J. Patronas, J. Smirniotopoulos, P. Herscovitch, W. Dieckman, C. Millo, D. Maric, G.P. Chatain, C.P. Hayes, S. Benzo, G. Scott, N. Edwards, A. Ray Chaudhury, M.B. Lodish, S. Sharma, L.K. Nieman, C.A. Stratakis, R.R. Lonser, P. Chittiboina, CRH stimulation improves (18)F-FDG-PET detection of pituitary adenomas in Cushing's disease. Endocrine 65(1), 155-165 (2019). https://doi.org/10.1007/s12020-019-01944-7

52. R.B. Friedman, E.H. Oldfield, L.K. Nieman, G.P. Chrousos, J.L. Doppman, G.B. Cutler Jr., D.L. Loriaux, Repeat transsphenoidal surgery for Cushing's disease. J. Neurosurg. 71(4), 520-527 (1989)

53. M. Buchfelder, S. Schlaffer, Pituitary surgery for Cushing's disease. Neuroendocrinology 92(Suppl 1), 102-106 (2010). https://doi.org/10.1159/000314223

54. G. Rubinstein, A. Osswald, S. Zopp, K. Ritzel, M. Theodoropoulou, F. Beuschlein, M. Reincke, Therapeutic options after surgical failure in Cushing's disease: A critical review. Best practice \& research. Clin. Endocrinol. Metab. 33(2), 101270 (2019). https://doi.org/10.1016/j.beem.2019.04.004

55. J. Honegger, F. Grimm, The experience with transsphenoidal surgery and its importance to outcomes. Pituitary 21(5), 545-555 (2018). https://doi.org/10.1007/s11102-018-0904-4

56. P. Valderrábano, J. Aller, L. García-Valdecasas, J. García-Uría, L. Martín, N. Palacios, J. Estrada, Results of repeated transsphenoidal surgery in Cushing's disease. Long-term follow-up. Endocrinologia y nutricion: organo de la Sociedad Espanola de. Endocrinol. Nutr. 61(4), 176-183 (2014). https://doi.org/10. 1016/j.endonu.2013.10.008

57. B.M. Hofmann, M. Hlavac, R. Martinez, M. Buchfelder, O.A. Müller, R. Fahlbusch, Long-term results after microsurgery for Cushing disease: experience with 426 primary operations over 35 years. J. Neurosurg. 108(1), 9-18 (2008). https://doi.org/10. 3171/jns/2008/108/01/0009

58. C.G. Patil, A. Veeravagu, D.M. Prevedello, L. Katznelson, M.L. Vance, E.R. Laws Jr., Outcomes after repeat transsphenoidal surgery for recurrent Cushing's disease. Neurosurgery 63(2), 266-270 (2008). https://doi.org/10.1227/01.neu.0000313117. 35824.9f. discussion 270-261

59. M.A. Wagenmakers, R.T. Netea-Maier, E.J. van Lindert, H.J. Timmers, J.A. Grotenhuis, A.R. Hermus, Repeated transsphenoidal pituitary surgery (TS) via the endoscopic technique: a good therapeutic option for recurrent or persistent Cushing's disease (CD). Clin. Endocrinol. 70(2), 274-280 (2009). https:// doi.org/10.1111/j.1365-2265.2008.03334.x

60. R. Pivonello, M. De Leo, A. Cozzolino, A. Colao, The treatment of cushing's disease. Endocr. Rev. 36(4), 385-486 (2015). https://doi.org/10.1210/er.2013-1048

61. K. Thakkar, A. Lila, V. Sarathi, S. Ramteke-Jadhav, M. Goroshi, S.S. Memon, R. Krishnatry, T. Gupta, R. Jalali, A. Goel, A. Shah, S. Sankhe, V. Patil, T. Bandgar, N.S. Shah, Cabergoline may act as a radioprotective agent in Cushing's disease. Clin. Endocrinol. 92(1), 55-62 (2020). https://doi.org/10.1111/cen.14123 
62. N. Ironside, C.J. Chen, C.C. Lee, D.M. Trifiletti, M.L. Vance, J. P. Sheehan, Outcomes of pituitary radiation for cushing's disease. Endocrinol. Metab. Clin. North Am. 47(2), 349-365 (2018). https://doi.org/10.1016/j.ecl.2018.01.002

63. S. Budyal, A.R. Lila, R. Jalali, T. Gupta, R. Kasliwal, V.S. Jagtap, T. Bandgar, P. Menon, N.S. Shah, Encouraging efficacy of modern conformal fractionated radiotherapy in patients with uncured Cushing's disease. Pituitary 17(1), 60-67 (2014). https://doi.org/10.1007/s11102-013-0466-4

64. G. Minniti, M. Osti, M.L. Jaffrain-Rea, V. Esposito, G. Cantore, R. Maurizi Enrici, Long-term follow-up results of postoperative radiation therapy for Cushing's disease. J. Neuro-oncol. 84(1), 79-84 (2007). https://doi.org/10.1007/s11060-007-9344-0

65. J. Estrada, M. Boronat, M. Mielgo, R. Magallón, I. Millan, S. Díez, T. Lucas, B. Barceló, The long-term outcome of pituitary irradiation after unsuccessful transsphenoidal surgery in Cushing's disease. New Engl. J. Med. 336(3), 172-177 (1997)

66. S.J. Hentschel, I.E. McCutcheon, Stereotactic radiosurgery for Cushing disease. Neurosurg. Focus 16(4), 1-7 (2004)

67. N.M. Oyesiku, Stereotactic radiosurgery for Cushing disease: a review. Neurosurg. Focus 23(6), E14 (2007). https://doi.org/10. 3171/FOC-07/12/E14

68. M.J. Shepard, G.U. Mehta, Z. Xu, H. Kano, N. Sisterson, Y.-H. $\mathrm{Su}, \mathrm{M}$. Krsek, A.M. Nabeel, A. El-Shehaby, K.A. Kareem, N. Martinez-Moreno, D. Mathieu, B.J. McShane, K. Blas, D. Kondziolka, I. Grills, J.Y. Lee, R. Martinez-Alvarez, W.A. Reda, R. Liscak, C.-C. Lee, L.D. Lunsford, M. Lee Vance, J.P. Sheehan, Technique of whole-sellar stereotactic radiosurgery for cushing disease: results from a multicenter, international cohort study. World Neurosurg. 116, e670-e679 (2018). https://doi.org/ 10.1016/j.wneu.2018.05.067

69. J.M. Sheehan, M.L. Vance, J.P. Sheehan, D.B. Ellegala, E.R. Laws Jr, Radiosurgery for Cushing's disease after failed transsphenoidal surgery. J. Neurosurg. 93(5), 738-742 (2000). https:// doi.org/10.3171/jns.2000.93.5.0738

70. G.U. Mehta, D. Ding, M.R. Patibandla, H. Kano, N. Sisterson, Y. H. Su, M. Krsek, A.M. Nabeel, A. El-Shehaby, K.A. Kareem, N. Martinez-Moreno, D. Mathieu, B. McShane, K. Blas, D. Kondziolka, I. Grills, J.Y. Lee, R. Martinez-Alvarez, W.A. Reda, R. Liscak, C.C. Lee, L.D. Lunsford, M.L. Vance, J.P. Sheehan, Stereotactic radiosurgery for cushing disease: results of an international, multicenter study. The J. Clin. Endocrinol. Metab. 102 (11), 4284-4291 (2017). https://doi.org/10.1210/jc.2017-01385

71. M.K. Aghi, J. Petit, P. Chapman, J. Loeffler, A. Klibanski, B.M. Biller, B. Swearingen, Management of recurrent and refractory Cushing's disease with reoperation and/or proton beam radiosurgery. Clin. Neurosurg. 55, 141-144 (2008)

72. J.M. Moore, E. Sala, A. Amorin, H. Martinez Jr., A.C. Bhowmik, S.D. Chang, S.G. Soltys, G.R. Harsh, L. Katznelson, CyberKnife radiosurgery in the multimodal management of patients with cushing disease. World Neurosurg. 112, e425-e430 (2018). https://doi.org/10.1016/j.wneu.2018.01.057

73. G.U. Mehta, D. Ding, A. Gupta, H. Kano, N.D. Sisterson, N. Martinez-Moreno, M. Kršek, H.C. Yang, C.C. Lee, R. Liščák, R. Martinez-Alvarez, L.D. Lunsford, M.L. Vance, J.P. Sheehan, Repeat stereotactic radiosurgery for Cushing's disease: outcomes of an international, multicenter study. J. Neuro-oncol. 138(3), 519-525 (2018). https://doi.org/10.1007/s11060-018-2817-5

74. A. Bunevicius, D. Sheehan, M. Lee Vance, D. Schlesinger, J.P. Sheehan, Outcomes of Cushing's disease following Gamma Knife radiosurgery: effect of a center's growing experience and era of treatment. J. Neurosurg. 1-8 (2020). https://doi.org/10. 3171/2019.12.jns 192743

75. L.H.A. Broersen, M. Jha, N.R. Biermasz, A.M. Pereira, O.M. Dekkers, Effectiveness of medical treatment for Cushing's syndrome: a systematic review and meta-analysis. Pituitary $\mathbf{2 1}$ (6), 631-641 (2018). https://doi.org/10.1007/s11102-018-0897-z

76. A. Lacroix, F. Gu, W. Gallardo, R. Pivonello, Y. Yu, P. Witek, M. Boscaro, R. Salvatori, M. Yamada, L. Tauchmanova, M. Roughton, S. Ravichandran, S. Petersenn, B.M.K. Biller, J. Newell-Price, Efficacy and safety of once-monthly pasireotide in Cushing's disease: a 12 month clinical trial. Lancet Diabetes Endocrinol. 6(1), 17-26 (2018). https://doi.org/10.1016/s22138587(17)30326-1

77. A. Lacroix, F. Gu, J. Schopohl, A. Kandra, A.M. Pedroncelli, L. Jin, R. Pivonello, Pasireotide treatment significantly reduces tumor volume in patients with Cushing's disease: results from a Phase 3 study. Pituitary 23(3), 203-211 (2020). https://doi.org/ 10.1007/s11102-019-01021-2

78. R. Palui, J. Sahoo, S. Kamalanathan, S.S. Kar, S. Selvarajan, H. Durgia, Effect of cabergoline monotherapy in Cushing's disease: an individual participant data meta-analysis. J. Endocrinol. Investig. 41(12), 1445-1455 (2018). https://doi.org/10.1007/ s40618-018-0936-7

79. M. Fleseriu, R. Pivonello, J. Young, A.H. Hamrahian, M.E. Molitch, C. Shimizu, T. Tanaka, A. Shimatsu, T. White, A. Hilliard, C. Tian, N. Sauter, B.M. Biller, X. Bertagna, Osilodrostat, a potent oral 11beta-hydroxylase inhibitor: 22-week, prospective, Phase II study in Cushing's disease. Pituitary 19(2), 138-148 (2016). https://doi.org/10.1007/s11102-015-0692-z

80. M. Fleseriu, R. Pivonello, A. Elenkova, R. Salvatori, R.J. Auchus, R.A. Feelders, E.B. Geer, Y. Greenman, P. Witek, F. Cohen, B.M. K. Biller, Efficacy and safety of levoketoconazole in the treatment of endogenous Cushing's syndrome (SONICS): a phase 3, multicentre, open-label, single-arm trial. Lancet Diabetes Endocrinol. (2019). https://doi.org/10.1016/s2213-8587(19)30313-4

81. H. Hunt, K. Donaldson, M. Strem, V. Zann, P. Leung, S. Sweet, A. Connor, D. Combs, J. Belanoff, Assessment of safety, tolerability, pharmacokinetics, and pharmacological effect of orally administered CORT125134: an adaptive, double-blind, randomized, placebo-controlled phase 1 clinical study. Clin. Pharmacol. Drug Dev. 7(4), 408-421 (2018). https://doi.org/10.1002/cpdd.389

82. F. Langlois, J. Chu, M. Fleseriu, Pituitary-directed therapies for cushing's disease. Front. Endocrinol 9, 164 (2018). https://doi. org/10.3389/fendo.2018.00164

83. M. Reincke, K. Ritzel, A. Osswald, C. Berr, G. Stalla, K. Hallfeldt, N. Reisch, J. Schopohl, F. Beuschlein, A critical reappraisal of bilateral adrenalectomy for ACTH-dependent Cushing's syndrome. Eur. J. Endocrinol. 173(4), M23-M32 (2015). https://doi.org/10.1530/eje-15-0265

84. K. Ritzel, F. Beuschlein, A. Mickisch, A. Osswald, H.J. Schneider, J. Schopohl, M. Reincke, Clinical review: outcome of bilateral adrenalectomy in Cushing's syndrome: a systematic review. J. Clin. Endocrinol. Metab. 98(10), 3939-3948 (2013). https://doi.org/10.1210/jc.2013-1470

85. A. Osswald, E. Plomer, C. Dimopoulou, M. Milian, R. Blaser, K. Ritzel, A. Mickisch, F. Knerr, M. Stanojevic, K. Hallfeldt, J. Schopohl, K.A. Kuhn, G. Stalla, F. Beuschlein, M. Reincke, Favorable long-term outcomes of bilateral adrenalectomy in Cushing's disease. Eur. J. Endocrinol. 171(2), 209-215 (2014). https://doi.org/10.1530/eje-14-0214

86. G. Assié, H. Bahurel, J. Bertherat, M. Kujas, P. Legmann, X. Bertagna, The Nelson's syndrome revisited. Pituitary 7(4), 209-215 (2004). https://doi.org/10.1007/s11102-005-1403-y

87. J. Patel, J.A. Eloy, J.K. Liu, Nelson's syndrome: a review of the clinical manifestations, pathophysiology, and treatment strategies. Neurosurg. Focus 38(2), E14 (2015). https://doi.org/10. 3171/2014.10.focus 14681

88. A. Gil-Cárdenas, M.F. Herrera, A. Díaz-Polanco, J.M. Rios, J.P. Pantoja, Nelson's syndrome after bilateral adrenalectomy for 
Cushing's disease. Surgery 141(2), 147-151 (2007). https://doi. org/10.1016/j.surg.2006.12.003. discussion 151-142

89. J. Park, A. De Luca, H. Dutton, J.C. Malcolm, M.A. Doyle, Cardiovascular outcomes in autonomous cortisol secretion and nonfunctioning adrenal adenoma: a systematic review. J. Endocr. Soc. 3(5), 996-1008 (2019). https://doi.org/10.1210/js. 2019-00090

90. T.B. Carroll, B.R. Javorsky, J.W. Findling, Postsurgical recurrent Cushing disease: clinical benefit of early intervention in patients with normal urinary free cortisol. Endocr. Pract. 22(10), 1216-1223 (2016). https://doi.org/10.4158/ep161380.or

91. J.K. Lambert, L. Goldberg, S. Fayngold, J. Kostadinov, K.D. Post, E.B. Geer, Predictors of mortality and long-term outcomes in treated Cushing's disease: a study of 346 patients. J. Clin. Endocrinol. Metab. 98(3), 1022-1030 (2013). https://doi.org/10. 1210/jc.2012-2893

92. J. Newell-Price, L.K. Nieman, M. Reincke, A. Tabarin, Endocrinology in the time of COVID-19: management of Cushing's syndrome. Eur. J. Endocrinol. 183(1), G1-G7 (2020). https://doi. org/10.1530/EJE-20-0352

93. B.M. Biller, A.B. Grossman, P.M. Stewart, S. Melmed, X. Bertagna, J. Bertherat, M. Buchfelder, A. Colao, A.R. Hermus, L.J. Hofland, A. Klibanski, A. Lacroix, J.R. Lindsay, J. NewellPrice, L.K. Nieman, S. Petersenn, N. Sonino, G.K. Stalla, B. Swearingen, M.L. Vance, J.A. Wass, M. Boscaro, Treatment of adrenocorticotropin-dependent Cushing's syndrome: a consensus statement. J. Clin. Endocrinol. Metab. 93(7), 2454-2462 (2008). https://doi.org/10.1210/jc.2007-2734

94. F. Cavagnini, F. Pecori Giraldi, Epidemiology and follow-up of Cushing's disease. Annales d'endocrinologie 62(2), 168-172 (2001)

95. J. Flitsch, U.J. Knappe, D.K. Lüdecke, The use of postoperative ACTH levels as a marker for successful transsphenoidal microsurgery in Cushing's disease. Zentralblatt fur Neurochirurgie 64 (1), 6-11 (2003). https://doi.org/10.1055/s-2003-37145

96. G.D. Hammer, J.B. Tyrrell, K.R. Lamborn, C.B. Applebury, E.T. Hannegan, S. Bell, R. Rahl, A. Lu, C.B. Wilson, Transsphenoidal microsurgery for Cushing's disease: initial outcome and long-term results. J. Clin. Endocrinol. Metab. 89(12), 6348-6357 (2004). https://doi.org/10.1210/jc.2003-032180

97. C. Dimopoulou, J. Schopohl, W. Rachinger, M. Buchfelder, J. Honegger, M. Reincke, G.K. Stalla, Long-term remission and recurrence rates after first and second transsphenoidal surgery for Cushing's disease: care reality in the Munich Metropolitan Region. Eur. J. Endocrinol. 170(2), 283-292 (2014). https://doi. org/10.1530/eje-13-0634

98. C. Invitti, F. Pecori Giraldi, M. de Martin, F. Cavagnini, Diagnosis and management of Cushing's syndrome: results of an Italian multicentre study. Study Group of the Italian Society of Endocrinology on the Pathophysiology of the HypothalamicPituitary-Adrenal Axis. T J. Clin. Endocrinol. Metab. 84(2), 440-448 (1999). https://doi.org/10.1210/jcem.84.2.5465

99. J. Jagannathan, R. Smith, H.L. DeVroom, A.O. Vortmeyer, C.A. Stratakis, L.K. Nieman, E.H. Oldfield, Outcome of using the histological pseudocapsule as a surgical capsule in Cushing disease. J. Neurosurg. 111(3), 531-539 (2009). https://doi.org/ 10.3171/2008.8.jns08339

100. S. Jehle, J.E. Walsh, P.U. Freda, K.D. Post, Selective use of bilateral inferior petrosal sinus sampling in patients with adrenocorticotropin-dependent Cushing's syndrome prior to transsphenoidal surgery. J. Clin. Endocrinol. Metab. 93(12), 4624-4632 (2008). https://doi.org/10.1210/jc.2008-0979

101. G. Rollin, N.P. Ferreira, M.A. Czepielewski, Prospective evaluation of transsphenoidal pituitary surgery in 108 patients with Cushing's disease. Arq Brasileiros de Endocrinol. e Metabologia
51(8), 1355-1361 (2007). https://doi.org/10.1590/s000427302007000800022

102. N. Sonino, M. Zielezny, G.A. Fava, F. Fallo, M. Boscaro, Risk factors and long-term outcome in pituitary-dependent Cushing's disease. J. Clin. Endocrinol. Metab. 81(7), 2647-2652 (1996). https://doi.org/10.1210/jcem.81.7.8675592

103. P.C. Johnston, L. Kennedy, A.H. Hamrahian, Z. Sandouk, J. Bena, B. Hatipoglu, R.J. Weil, Surgical outcomes in patients with Cushing's disease: the Cleveland clinic experience. Pituitary 20(4), 430-440 (2017)

104. W.F. Chandler, A.L. Barkan, T. Hollon, A. Sakharova, J. Sack, B. Brahma, D.E. Schteingart, Outcome of transsphenoidal surgery for Cushing Disease: a single-center experience over 32 Years. Neurosurgery 78(2), 216-223 (2016)

105. K.I. Alexandraki, G.A. Kaltsas, A.M. Isidori, H.L. Storr, F. Afshar, I. Sabin, S.A. Akker, S.L. Chew, W.M. Drake, J.P. Monson, G.M. Besser, A.B. Grossman, Long-term remission and recurrence rates in Cushing's disease: predictive factors in a single-centre study. Eur. J. Endocrinol. 168(4), 639-648 (2013). https://doi.org/10.1530/eje-12-0921

106. P. Bansal, A. Lila, M. Goroshi, S. Jadhav, N. Lomte, K. Thakkar, A. Goel, A. Shah, S. Sankhe, N. Goel, N. Jaguste, T. Bandgar, N. Shah, Duration of post-operative hypocortisolism predicts sustained remission after pituitary surgery for Cushing's disease. Endocr. Connect. 6(8), 625-636 (2017)

107. J.E. Boggan, J.B. Tyrrell, C.B. Wilson, Transsphenoidal microsurgical management of Cushing's disease. Report of 100 cases. J. Neurosurg. 59(2), 195-200 (1983). https://doi.org/10.3171/jns. 1983.59.2.0195

108. R. Bou Khalil, C. Baudry, L. Guignat, C. Carrasco, J. Guibourdenche, S. Gaillard, X. Bertagna, J. Bertherat, Sequential hormonal changes in 21 patients with recurrent Cushing's disease after successful pituitary surgery. Eur. J. Endocrinol. 165(5), 729-737 (2011). https://doi.org/10.1530/eje-11-0424

109. J.C. Chen, A.P. Amar, S. Choi, P. Singer, W.T. Couldwell, M.H. Weiss, Transsphenoidal microsurgical treatment of Cushing disease: postoperative assessment of surgical efficacy by application of an overnight low-dose dexamethasone suppression test. J. Neurosurg. 98(5), 967-973 (2003). https://doi.org/10.3171/jns. 2003.98.5.0967

110. B.M. Hofmann, R. Fahlbusch, Treatment of Cushing's disease: a retrospective clinical study of the latest 100 cases. Front. Horm. Res. 34, 158-184 (2006). https://doi.org/10.1159/000091580

111. U.J. Knappe, D.K. Lüdecke, Persistent and recurrent hypercortisolism after transsphenoidal surgery for Cushing's disease. Acta Neurochirurgica 65, 31-34 (1996). https://doi.org/10.1007/ 978-3-7091-9450-8_10

112. T. Nakane, A. Kuwayama, M. Watanabe, T. Takahashi, T. Kato, K. Ichihara, N. Kageyama, Long term results of transsphenoidal adenomectomy in patients with Cushing's disease. Neurosurgery 21(2), 218-222 (1987). https://doi.org/10.1227/00006123198708000-00015

113. D.M. Prevedello, N. Pouratian, J. Sherman, J.A. Jane Jr., M.L. Vance, M.B. Lopes, E.R. Laws Jr., Management of Cushing's disease: outcome in patients with microadenoma detected on pituitary magnetic resonance imaging. J. Neurosurg. 109(4), 751-759 (2008). https://doi.org/10.3171/jns/2008/109/10/0751

114. E. Valassi, B.M. Biller, B. Swearingen, F. Pecori Giraldi, M. Losa, P. Mortini, D. Hayden, F. Cavagnini, A. Klibanski, Delayed remission after transsphenoidal surgery in patients with Cushing's disease. J. Clin. Endocrinol. Metab. 95(2), 601-610 (2010). https://doi.org/10.1210/jc.2009-1672

115. M. Feng, Z. Liu, X. Liu, X. Bao, Y. Yao, K. Deng, B. Xing, W. Lian, H. Zhu, L. Lu, R. Wang, Diagnosis and outcomes of 341 patients with Cushing's disease following transsphenoid surgery: 
a single-center experience. World Neurosurg. 109, e75-e80 (2018). https://doi.org/10.1016/j.wneu.2017.09.105

116. S. Cannavò, B. Almoto, C. Dall'Asta, S. Corsello, R.M. Lovicu, E. De Menis, F. Trimarchi, B. Ambrosi, Long-term results of treatment in patients with ACTH-secreting pituitary macroadenomas. Eur. J. Endocrinol. 149(3), 195-200 (2003). https:// doi.org/10.1530/eje.0.1490195

117. G.F. Pieters, A.R. Hermus, E. Meijer, A.G. Smals, P.W. Kloppenborg, Predictive factors for initial cure and relapse rate after pituitary surgery for Cushing's disease. J. Clin. Endocrinol. Metab. 69(6), 1122-1126 (1989)

118. J.R. Lindsay, E.H. Oldfield, C.A. Stratakis, L.K. Nieman, The postoperative basal cortisol and CRH tests for prediction of longterm remission from Cushing's disease after transsphenoidal surgery. J. Clin. Endocrinol. Metab. 96(7), 2057-2064 (2011)

119. G. Aranda, J. Enseñat, M. Mora, M. Puig-Domingo, M.J. Martínez de Osaba, G. Casals, E. Verger, M.T. Ribalta, F.A. Hanzu, I. Halperin, Long-term remission and recurrence rate in a cohort of Cushing's disease: the need for long-term follow-up. Pituitary 18(1), 142-149 (2015). https://doi.org/10.1007/s11102014-0567-8

120. T. Imaki, T. Tsushima, N. Hizuka, E. Odagiri, Y. Murata, T. Suda, K. Takano, Postoperative plasma cortisol levels predict long-term outcome in patients with Cushing's disease and determine which patients should be treated with pituitary irradiation after surgery. Endocr. J. 48(1), 53-62 (2001)

121. N. Ironside, G. Chatain, D. Asuzu, S. Benzo, M. Lodish, S. Sharma, L. Nieman, C.A. Stratakis, R.R. Lonser, P. Chittiboina, Earlier post-operative hypocortisolemia may predict durable remission from Cushing's disease. Eur. J. Endocrinol. 178(3), 255-263 (2018)

122. M. Mayberg, S. Reintjes, A. Patel, K. Moloney, J. Mercado, A. Carlson, J. Scanlan, F. Broyles, Dynamics of postoperative serum cortisol after transsphenoidal surgery for Cushing's disease: implications for immediate reoperation and remission. J. Neurosurg. 129(5), 1268-1277 (2018)

123. G.C. Toms, M.I. McCarthy, M.J. Niven, C.H. Orteu, T.T. King, J.P. Monson, Predicting relapse after transsphenoidal surgery for Cushing's disease. J. Clin. Endocrinol. Metab. 76(2), 291-294 (1993)

124. P. Abellán-Galiana, C. Fajardo-Montañana, P. Riesgo-Suárez, M. Pérez-Bermejo, C. Ríos-Pérez, J. Gómez-Vela, Prognostic usefulness of ACTH in the postoperative period of Cushing's disease. Endocr. Connect. 8(9), 1262-1272 (2019)

125. A.L. Serban, G. Del Sindaco, E. Sala, G. Carosi, R. Indirli, G. Rodari, C. Giavoli, M. Locatelli, G. Carrabba, G. Bertani, G. Marfia, G. Mantovani, M. Arosio, E. Ferrante, Determinants of outcome of transsphenoidal surgery for Cushing disease in a single-centre series. J. Endocrinol. Investig. 43(5), 631-639 (2020)

126. A. Selek, B. Cetinarslan, Z. Canturk, I. Tarkun, O.Z. Akyay, B. Cabuk, S. Ceylan, The utility of preoperative ACTH/cortisol ratio for the diagnosis and prognosis of cushing's disease. J. Neurosci. Rural Pract. 9(1), 106-111 (2018)

127. D.A. Rees, F.W. Hanna, J.S. Davies, R.G. Mills, J. Vafidis, M.F. Scanlon, Long-term follow-up results of transsphenoidal surgery for Cushing's disease in a single centre using strict criteria for remission. Clin. Endocrinol. 56(4), 541-551 (2002). https://doi. org/10.1046/j.1365-2265.2002.01511.x
128. D.J. Romanholi, M.C. Machado, C.C. Pereira, D.S. Danilovic, M.A. Pereira, V.A. Cescato, M.B. Cunha Neto, N.R. Musolino, B.B. de Mendonça, L.R. Salgado, Role for postoperative cortisol response to desmopressin in predicting the risk for recurrent Cushing's disease. Clin. Endocrinol. 69(1), 117-122 (2008). https://doi.org/10.1111/j.1365-2265.2007.03168.x

129. R. Valéro, S. Vallette-Kasic, B. Conte-Devolx, P. Jaquet, T. Brue, The desmopressin test as a predictive factor of outcome after pituitary surgery for Cushing's disease. Eur. J. Endocrinol. 151(6), 727-733 (2004). https://doi.org/10.1530/eje.0.1510727

130. D.A. Vassiliadi, M. Balomenaki, A. Asimakopoulou, E. Botoula, M. Tzanela, S. Tsagarakis, The desmopressin test predicts better than basal cortisol the long-term surgical outcome of cushing's disease. J. Clin. Endocrinol. Metab. 101(12), 4878-4885 (2016)

131. M. Losa, R. Bianchi, R. Barzaghi, M. Giovanelli, P. Mortini, Persistent adrenocorticotropin response to desmopressin in the early postoperative period predicts recurrence of Cushing's disease. J. Clin. Endocrinol. Metab. 94(9), 3322-3328 (2009)

132. P. Le Marc'hadour, M. Muller, F. Albarel, A.L. Coulon, I. Morange, M. Martinie, E. Gay, T. Graillon, H. Dufour, B. ConteDevolx, O. Chabre, T. Brue, F. Castinetti, Postoperative followup of Cushing's disease using cortisol, desmopressin and coupled dexamethasone-desmopressin tests: a head-to-head comparison. Clin. Endocrinol. 83(2), 216-222 (2015). https://doi.org/ 10.1111/cen.12739

133. M. Barbot, N. Albiger, S. Koutroumpi, F. Ceccato, A.C. Frigo, R. Manara, A. Fassina, M.P. Gardiman, M. Scanarini, F. Mantero, C. Scaroni, Predicting late recurrence in surgically treated patients with Cushing's disease. Clin. Endocrinol. 79(3), 394-401 (2013)

134. M. Losa, P. Mortini, S. Dylgjeri, R. Barzaghi, A. Franzin, C. Mandelli, M. Giovanelli, Desmopressin stimulation test before and after pituitary surgery in patients with Cushing's disease. Clin. Endocrinol. 55(1), 61-68 (2001). https://doi.org/10.1046/j. 1365-2265.2001.01324.x

135. M.O. van Aken, W.W. de Herder, A.J. van der Lely, F.H. de Jong, S.W: Lamberts, Postoperative metyrapone test in the early assessment of outcome of pituitary surgery for Cushing's disease. Clin. Endocrinol. 47(2), 145-149 (1997). https://doi.org/10. 1046/j.1365-2265.1997.2541051.x

136. E. Uvelius, P. Höglund, S. Valdemarsson, P. Siesjö, An early post-operative ACTH suppression test can safely predict shortand long-term remission after surgery of Cushing's disease. Pituitary 21(5), 490-498 (2018). https://doi.org/10.1007/s11102018-0902-6

137. X. Bertagna, L. Guignat, Approach to the Cushing's disease patient with persistent/recurrent hypercortisolism after pituitary surgery. J. Clin. Endocrinol. Metab. 98(4), 1307-1318 (2013). https://doi.org/10.1210/jc.2012-3200

138. M. Fleseriu, Medical treatment of Cushing disease: new targets, new hope. Endocrinol. Metab. Clinics North Am. 44(1), 51-70 (2015). https://doi.org/10.1016/j.ecl.2014.10.006

139. M. Fleseriu, S. Petersenn, Medical therapy for Cushing's disease: adrenal steroidogenesis inhibitors and glucocorticoid receptor blockers. Pituitary 18(2), 245-252 (2015). https://doi.org/10. 1007/s11102-014-0627-0 